\title{
Elimination of Sarcoptes scabiei in Pig Herds by Single or Double Administrations of an Avermectin
}

\author{
By M. Jacobson ${ }^{1}$, S. Bornstein ${ }^{2}$, E. Palmér ${ }^{3}$ and P. Wallgren ${ }^{2}$ \\ ${ }^{1}$ Department of Large Animal Clinical Sciences, Faculty of Veterinary Medicine, Swedish University of Agri- \\ cultural Sciences, ${ }^{2}$ National Veterinary Institute, Uppsala, and ${ }^{3}$ Pfizer AB,Täby, Sweden.
}

\begin{abstract}
Jacobsen M, Bornstein S, Palmér E, Wallgren P: Elimination of Sarcoptes scabiei in pig herds by single or double administrations of an avermectin. Acta vet. scand. 2000, 41, 227-235. - Attempts to eliminate Sarcoptes scabiei var. suis were made in 2 piglet producing herds by intramuscular injections with doramectin (Dectomax ${ }^{\mathrm{TM}}$, Pfizer inc., New York, USA). No hygienic measures of the environments were undertaken. In herd A, all animals were treated twice at a 14-day interval. Theoretically it should be possible to eliminate the mite with a single injection and therefore the animals in herd B were treated only once. The results were measured by attempts to demonstrate S. scabiei by skin scrapings, by recording skin lesions, by establishing rubbing indexes, and by measuring serum antibodies to $S$. scabiei. All adult animals greater than 8 months of age and 15 weaned piglets 8-16 weeks of age per herd were investigated prior to treatments and every fourth month for a total of 20 months following administration of the treatments. Live S. scabiei were demonstrated prior to treatments in both herds, but no further. Skin lesion scores, rubbing indexes and serum antibody levels remained low throughout the study. It is possible to eliminate $S$. scabiei from a herd with one single injection of doramectin. Precautions must be taken to ensure that all animals get a correct dose and that the drug is properly administered.
\end{abstract}

macrocyclic lactone; doramectin; ELISA.

\section{Introduction}

Infections with the mite Sarcoptes scabiei var. suis cause a common disease known as sarcoptic mange (Sheahan 1974, Cargill \& Dobson 1977, Hollanders \& Vercruysse 1990). The disease usually begins with an acute hypersensitivity reaction (Sheahan 1974, Cargill \& Dobson 1977, Bornstein \& Zakrisson 1993) with clinical signs such as pruritus and urticarial wheals. In addition, the pigs often exhibit light encrustations in the ears. These encrustations either persist or may aggravate as the infection develops into chronic disease with skin lesions, particularly on the inner surface of the ear and distal parts of the body, but usually with a less pronounced pruritus (Sheahan 1974, Cargill \&
Dobson 1979a, Bornstein \& Zakrisson 1993). Affected pigs may be severely stressed and show reduced performance (Alva-Valdes et al. 1986, Cargill \& Dobson 1979b, Arends et al. 1990).

Different methods have been used to diagnose the disease, of which the most definite is demonstration of the parasite. This method is, however, stated to have a low sensitivity (Yeoman 1983, Kambarage 1993, Bornstein \& Wallgren 1997) and is therefore not considered to be a useful tool in herds with low to moderate clinical signs of mange, i.e. herds suffering from subclinical infections. Other diagnostic tools include counting of rubbing episodes over a set 
period of time, out of which a rubbing index can be calculated (Cargill \& Dobson 1979b, Hollanders et al. 1995, Davies 1995), measurement of skin lesions similar to those caused by mange and the calculation of a mean lesion score (Cargill \& Dobson 1979b, Pointon et al. 1987, Davies 1995), and demonstration of serum antibodies to $S$. scabiei by ELISA (Nöckler et al. 1992, Bornstein \& Zakrisson 1993). The latter method is the most specific of these diagnostic tools (Bornstein \& Wallgren 1997).

In order to reduce animal suffering and increase performance, attempts to eliminate mange at a herd level have been made during the last decades (Henriksen \& Ebbesen 1987, Hogg 1989, Lambers 1994). Generally these programmes have included repeated treatments of animals with effective acaricides in combination with a simultaneous emptying, cleaning and disinfection of the environment. As recently reported (Bornstein et al. 1994, Jacobson et al. 1999), it appears possible to perform such elimination programmes without any simultaneous environmental precautions. Thus the effectuation of such elimination programmes may be considerably facilitated and thereby more attractive to the farmers.

Different acaricides have been used in elimination programmes (Hogg 1989, Madsen 1990) but the avermectins have dominated, probably due to their systemic and prolonged effects (Courtney et al. 1983, Hogg 1984, Henriksen \& Ebbesen 1987). The only previously available macrocyclic lactone has been ivermectin (Ivo$\operatorname{mec}^{\circledR}$, Merial, Lyon, France), but recently new products, such as doramectin (Dectomax ${ }^{\circledR}$, Pfizer, New York, USA) and moxidectin (Cy$\operatorname{dectin}^{\circledR}$, Fort Dodge Animal Health, Kansas City, Missouri, USA) have entered the market. Doramectin is an avermectin registered for use in pigs administered by intramuscular injection. In pigs the avermectins are considered to have a clinical duration of 9 to 18 days, during which no reinfections will occur (Arends et al. 1999). The sarcoptic mite is only able to survive outside the host for a short period (Mikhalochkina 1975). Taking the life cycle of the parasite (Soulsby 1982, Hogg 1989) into account, a single avermectin treatment of the animals appears to be sufficient to eliminate mange on herd level (Hogg 1984, Cargill et al. 1996). However, in this context it is important to consider that incorrect medication of one single animal probably will lead to failure of the elimination attempt. The aim of the present study was to compare the efficacy of using one or 2 treatments with an avermectin at attempts to eliminate $S$. scabiei on herd basis.

\section{Materials and methods}

\section{Herds}

The study was conducted in 2 conventional piglet-producing herds, designated A and B. Herd A comprised 35-41 sows during the study. Herd B initially comprised 21 sows and increased to 51 sows at the end of the trial (Table 1). Replacement gilts and boars were bought from nucleus herds. They were kept in quarantine for 4 weeks before entering the herds. In addition, herd B also kept a few fattening pigs on site at the beginning of the trial.

Both herds comprised one farrowing unit, one unit for dry sows on deep straw bedding, and one unit for weaned piglets at the age of 5-16 weeks. They performed continuous farrowing production and sold piglets at approximately $25-\mathrm{kg}$ body weight.

Low to moderate clinical signs of mange were present in both herds and S. scabiei was demonstrated by deep skin scrapings and by antibodies to $S$. scabiei, prior to treatments.

\section{Experimental design and treatment strategy}

The animals were restrained and doramectin was injected intramuscularly in the neck behind 
Table 1. The presence of Sarcoptes scabiei in skin scrapings from weaners and adults before and after initiating intramuscular administrations of doramectin. Doramectin was administered twice with an interval of 14 days in herd A, but only once in herd B. At each occasion, all adult animals and 15 weaners in each herd were sampled.

\begin{tabular}{lcccc}
\hline \multirow{2}{*}{$\begin{array}{l}\text { Time after initiating } \\
\text { treatment (months) }\end{array}$} & Weaners & Adults & & \multicolumn{2}{c}{ Herd B } \\
\cline { 2 - 3 } & & & Weaners & Adults \\
\hline 0 (before) & $5 / 15$ & $1 / 35$ & $3 / 15$ & $0 / 21^{2}$ \\
1 & $0 / 15$ & $0 / 35$ & $3 / 15$ & $0 / 22$ \\
4 & $0 / 15$ & $0 / 38$ & $0 / 15$ & $0 / 20$ \\
8 & $0 / 15$ & $0 / 39$ & $0 / 15$ & $0 / 46$ \\
12 & $0 / 15$ & $0 / 34$ & $0 / 15$ & $0 / 46$ \\
16 & $0 / 15$ & $0 / 40$ & $0 / 15$ & $0 / 57$ \\
20 & $0 / 15$ & $0 / 41$ & $0 / 15$ & $0 / 51$ \\
\hline
\end{tabular}

${ }^{1}$ Dead mites. ${ }^{2}$ S. scabiei was demonstrated in 6 out of 15 investigated fatteners present in herd B before effectuating the programme.

the ear, at a dosage of $300 \mu \mathrm{g}$ per $\mathrm{kg}$ body weight. All pigs above 5 days of age were weighed prior to treatment and their individual treatment dose was calculated. Newborn piglets were treated as soon as they reached the age of 5 days.

In herd $\mathrm{A}$, all pigs in the herd were injected twice at an interval of 14 days. In herd B, the animals received only one injection. No environmental acaricide treatment was undertaken. All replacement animals purchased after the initiation of the programme were kept for 28 days in isolation before entering the herds. During the quarantine, replacement stock for both farms were injected twice with doramectin, the first treatment immediately after arrival and the second treatment 2 weeks later.

\section{Monitoring}

The results of the studies were monitored by demonstration of live or dead S. scabiei, by assessing skin lesions associated with mange, by the calculation of a rubbing index and by demonstrations of serum antibodies with an ELISA (Bornstein \& Wallgren 1997). At each sampling occasion all adults and 15 weaners were sampled. Monitorings were conducted prior to treatment, at the day of the first treatment, and every fourth month. Monitoring continued for a period of 20 months onwards. An additional visit, during which skin lesions and rubbing indexes were recorded and skin scrapings were sampled, was made one month after the initial treatment. Blood samples were also collected from purchased replacement animals during their stay in the quarantine.

\section{Demonstration of S. scabiei}

Skin scrapings were taken with sharp plastic spoons from deep inside the pinnae of the ear of the pigs. The samples were mixed with glycerine and stored under light for 24-48 h. Live mites were searched for under microscope. If no mites were found, the samples were mixed with $10 \%$ potassiumhydroxide $(\mathrm{KOH})$ solution, centrifuged and examined for the presence of $S$. scabiei.

\section{Skin lesions and rubbing index}

Skin lesions similar to those caused by $S$. scabie $i$ were defined on a scale from 0 to $3(0=$ no lesions, $1=<1 \mathrm{~cm}$ in diameter, $2=1-2,5 \mathrm{~cm}$ in diameter, $3=>2,5 \mathrm{~cm}$ in diameter). These lesions included plaques, maculas, crusts and/or 


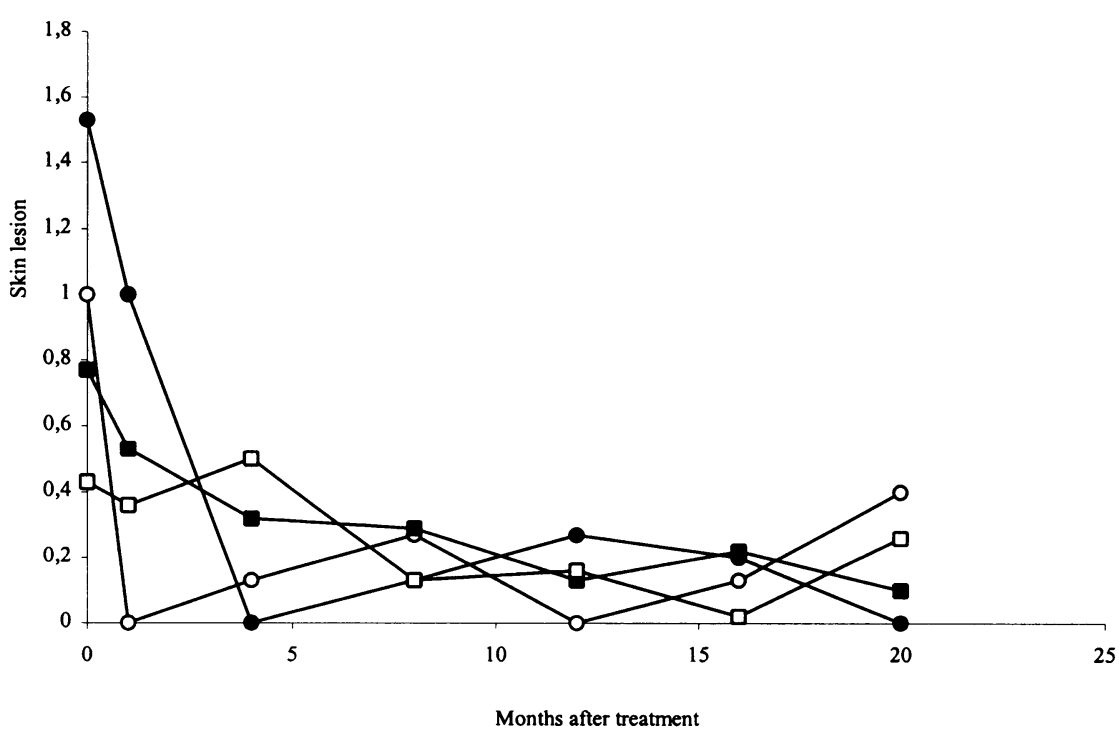

Figure 1. Skin lesions recorded among sows (squares) and offspring (circles) in herd A (filled symbols) and herd B (open symbols) before and after implementation of treatment programs aimed to eliminate Sarcoptes scabiei. The standard deviations varied from 0.0 to 0.89 .

hyperkeratosis. Rubbing indexes were calculated by observing and counting every rubbing episode of each adult animal and each group of weaners, respectively, for $15 \mathrm{~min}$. The observations were made in the middle of the day, separate from feeding. To achieve the rubbing index, the number of rubbings was divided by the number of individuals in the group.

\section{Antibodies to S. scabiei}

Blood samples without additives were collected by jugular vein punctures and the sera were stored at $-20^{\circ} \mathrm{C}$ until analysed. Antibodies to $\mathrm{S}$. scabiei were detected in serum diluted $1 / 200$ in PBS-Tween using an indirect ELISA previously described (Bornstein \& Zakrisson 1993, Bornstein \& Wallgren 1997). The ELISA was read at $492 \mathrm{~nm}$ and absorbance values above 0.175 and 0.08 were regarded as positive reactions in adult animals and weaners, respectively.

\section{Results}

Results obtained prior to treatments

The pigs exhibited low to moderate clinical signs of sarcoptic mange prior to treatments. Among weaners, the mean skin lesion score was $1.53 \pm 0.52$ in herd $A$, and $1.00 \pm 0.54$ in herd B. Among the adults, the mean lesion score was $0.77 \pm 0.92$ in herd $A$, and $0.43 \pm 0.06$ in herd B (Fig. 1).

The average rubbing index values recorded among weaners were 0.39 in herd A and 0.20 in herd B. Among adults, the corresponding figures were 0.74 and 0.00 , respectively (Fig. 2). Live $S$. scabiei mites were demonstrated in one of the adult animals by deep skin scrapings in herd A, and in 5 of the weaners (Table 1). In herd $\mathrm{B}$, live sarcoptic mites were found in 3 weaners and in 6 slaughter pigs.

The mean absorbance values of serum antibodies to $S$. scabiei were $0.16 \pm 0.12$ and $0.11 \pm$ 

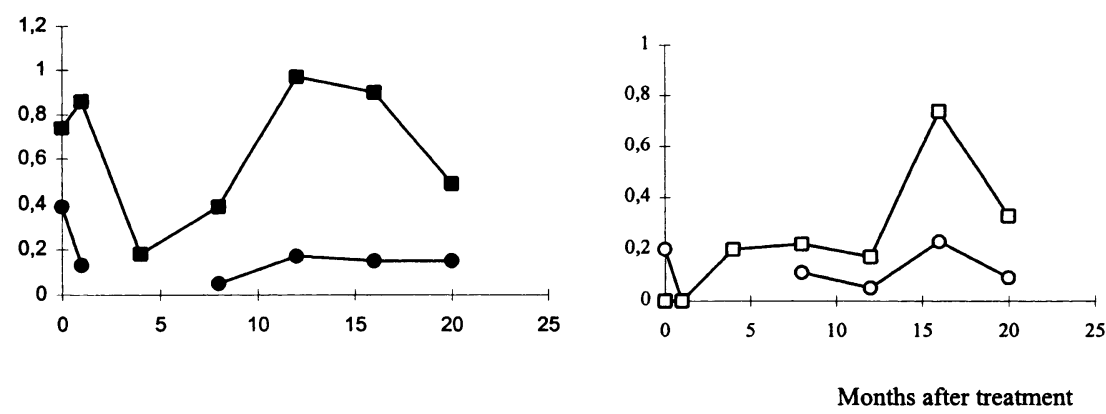

Figure 2. Rubbing indexes in adults (squares) and weaners (circles) in herd A (filled symbols) and B (open symbols), respectively. A marked seasonal variation was seen in the rubbing indexes among the adults. They were housed in deep straw bedded non-insulated barns. During the cold winter seasons they preferably buried themselves in the bed in-between feedings and thus showed an overall reduced activity.

0.08 among weaners in herd A and B, respectively. The corresponding values obtained in sera collected from adults were $0.17 \pm 0.06$ and $0.18 \pm 0.08$, respectively (Fig. 3).

\section{Results obtained following treatments}

No signs of clinical mange were observed in either herd A or herd B following the doramectin treatments. Nor was any adverse drug reaction observed. Skin lesion scores declined throughout the study. At the final inspection, 20 months after the first of 2 treatments in herd A, the skin lesions had declined to nil among the weaners and to $0.05 \pm 0.23$ among the adult animals in herd $\mathrm{A}$. In herd $\mathrm{B}$, at 20 months after a single treatment, the skin lesion score had declined to $0.40 \pm 0.63$ among the weaners, and to $0.25 \pm$ 0.60 among the adults (Fig. 1).

The rubbing indexes calculated for weaners remained low throughout the study (Fig. 2). A low incidence of rubbing episodes (less than 1 per animal during $15 \mathrm{~min}$ ) was also recorded among the adults. However, the rubbing incidence among adults fluctuated over time in both herds. As shown in fig. 2, the sows rubbed themselves more often during the summer.

In total 552 skin scrapings from adults and 225 samples from weaners at the age of 8-16 weeks, were analysed for the presence of mites. No live mange mites were found after administering the treatments. Dead S. scabiei mites were found by $\mathrm{KOH}$ treatment in 3 weaned piglets one month after the treatment in herd $\mathrm{B}$, but not later (Table 1).

The mean absorbance values of antibodies to $S$. scabiei measured in serum collected from weaners had decreased to $0.05 \pm 0.02$ in both herds 4 months after the treatments and remained at that level throughout the study (Fig. $3)$. Similarly, the mean antibody levels obtained in serum from sows had ranged between $0.11 \pm$ 0.03 and $0.13 \pm 0.04$ from 8 months after treatment and onwards in herd A. At the last sampling occasion, 20 month after treatment, the serum antibody levels had declined to $0.10 \pm$ 0.02 . In contrast the mean absorbance level of antibodies to $S$. scabiei in herd B actually increased from month 4 to month 8 , during which period the number of sows increased from 20 to 46 by the purchase of new gilts (Table 1). Thereafter the level of antibodies gradually decreased to a level of $0.13 \pm 0.04$ at the last sampling occasion. 


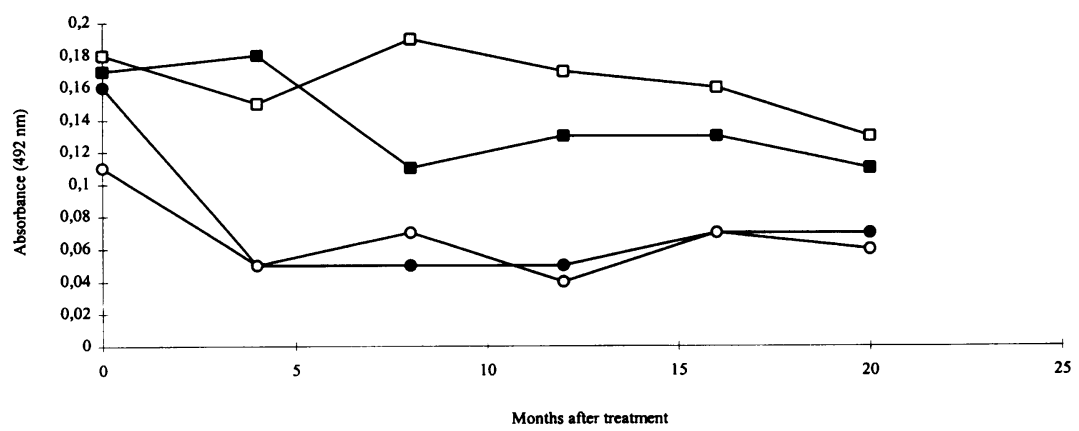

Figure 3. Mean absorbance values of antibodies to Sarcoptes scabiei in serum collected from weaners (circles) and from adults (squares) before and after the treatment with doramectin. The filled symbols represent herd $\mathrm{A}$ and the open symbols represent herd B (standard deviations in both herds varied from 0.01 to 0.07 through the study). The increased absorbance level among sows in herd B 8 months after the treatment, reflects the increase from 20 to 46 sows made by merchandise of seropositive sows.

\section{Discussion}

Due to the efficacy of modern acaricidal drugs it is possible to eliminate sarcoptic mange without undertaking any specific environmental acaricide hygienic measures (Bornstein et al. 1994, Jacobson et al. 1999). The life cycle of $S$. scabiei is stated to last for 10-15 days (Soulsby 1982), and the parasite is unable to survive away from its host for more than 12 days under natural conditions (Mikhalochkina 1975). The therapeutic effect of modern acaricidal drugs may persist for a longer period, therefore it might be possible to further simplify elimination attempts by employing only one single acaricidal treatment (Hogg 1984, Cargill et al. 1996, Arends et al. 1999).

The results obtained on one farm in this study agreed with this hypothesis in all substantial parts. No signs of mange infection were present following the elimination attempts, either by single or double intramuscular injections with doramectin. However, because no effect should be expected from drugs if deposited in fat tissue (Schultz et al. 1988), an increased risk for failure due to improper medical administration should be taken into account if treating the ani- mals only once. That risk will decrease if the animals are treated twice and by restraining the animals at treatment. Further, all pigs ought to be weighed before treatment since inadequate treatment of single pigs may hazard the success of eradication attempts (Hogg 1989). The danger of using a defined treatment dose for all sows was well elucidated by the heaviest sow in this study. She weighed $315 \mathrm{~kg}$, which corresponds to a treatment dose of $9.5 \mathrm{ml}$ doramectin $(300 \mu \mathrm{g} / \mathrm{kg}$ body weight).

The success of the elimination attempts was in both herds supported by a failure to demonstrate live mites 20 months after the initial treatment. The demonstration of dead mites in 3 pigs one month post treatment did not alter this standpoint since dead mites may persist for a long period in ear-wax (Hogg 1984, Cargill et al. 1996, Jacobson et al. 1999).

Clinical signs associated with mange, such as skin lesions and rubbing intensity, also indicated success of the treatments since these signs remained at a low level following the acaricidal treatments. Introduction of mites to juvenile animals are reported to rapidly induce 
signs of pruritus and papular dermatitis (Sheahan 1974, Cargill \& Dobson 1979a, Bornstein \& Zakrisson 1993). Therefore, failure of elimination attempts would certainly be obvious especially among naive piglets (Courtney et al. 1983, Bornstein \& Zakrisson 1993).

Although the number of rubbings recorded per adult always was below one per animal during $15 \mathrm{~min}$, the rubbing index of the adults did vary over time. The housing of dry sows in large deep straw-bedded pens located in un-insulated barns established seasonal climatic variations. The outdoor temperature may vary from the extremes of $-40^{\circ} \mathrm{C}$ and $+40^{\circ} \mathrm{C}$ over the year. The rubbing intensity was increased during the summer period in both herds, which corresponds to an overall increased activity of the animals (Fig. 2).

The success of the elimination attempts was also confirmed by decreasing levels of serum antibodies to $S$. scabiei among weaned piglets and breeding stock in both herds.

Acquired antibodies may remain for at least 9 months following acaricidal treatment (Bornstein et al. 1994). Care must therefore be paid to introduction of non-infected but seropositive replacement breeding stock when using serological methods as a tool to document freedom from infection. This dilemma was well elucidated in the present study. The initial mean absorbance level of serum antibodies to $S$. scabiei among all adults was 0.175 in both herds. In herd $\mathrm{A}$, which remained at the size of 40 sows throughout the study, that value decreased to 0.11 eight months later. A similar decrease was not seen until 20 months post treatment in herd B. Four months after the treatment and onward, herd $B$ increased the number of sows from 20 to 46 by purchase of seropositive gilts (data not shown). In the same context, decreasing levels of serum antibodies among weaners, following elimination attempts, may sometimes be difficult to certify in herds that exploit a low patho- gen load, i.e. herds that previously have performed a strategic use of acaricides in age segregated rearing systems (Bornstein \& Wallgren 1997). Serological monitoring for success of elimination attempts against $S$. scabiei must therefore be carefully planned and carried through.

In conclusion, it was found possible to eliminate $S$. scabiei using single or double intramuscular injections with doramectin without any other steps taken. It is important to use a proper administration and correct dosage of the drug. Regardless of strategy chosen, one must always consider the risk of reintroducing $S$. scabiei by purchase of pigs from herds with unknown mange status (Hogg 1984, Hogg 1989). Therefore, it is recommended to keep replacement animals in a quarantine for at least 3 weeks and, despite eventual previous treatments, treat these animals with an effective acaricide during this period.

\section{Acknowledgements}

We wish to thank E. Lööf and U. Nilsson who kindly put their herds at our disposal and gave us all possible assistance, and Mrs. B. Christensson and Mrs. S. Kvarforth at the laboratory of parasitology for skilful technical assistance.

\section{References}

Alva-Valdes $R$, Wallace DH, Foster AG, Ericsson $G F$, Wooden $J W$ : The effects of sarcoptic mange on the productivity of confined pigs. Food Anim. Pract. March, 1986, 258-262.

Arends JJ, Skogerboe TL, Ritzhaupt LK: Persistent efficacy of doramectin and ivermectin against experimental infestations of Sarcoptes scabiei var. suis in swine. Vet. Par. 1999, 82, 71-79.

Arends JJ, Stanislaw CM, Gerdon D: Effects of sarcoptic mange on lactating swine and growing pigs. J. Anim. Sci. 1990, 68, 1495-1499.

Bornstein, S, Fellström C, Thebo P, Wallgren P: Eradication of sarcoptic mange in a herd of pigs monitored by skin scrapings and ELISA. Proc. Int. Pig Vet. Soc. Congr. Bangkok, Thailand, 1994, 13,251 . 
Bornstein $S$, Wallgren $P$ : Serodiagnosis of sarcoptic mange in swine. Vet. Rec. 1997, 141, 8-12.

Bornstein S, Zakrisson G: Clinical picture and antibody response in pigs infected by Sarcoptes scabiei var. suis. Vet. Derm. 1993, 4,3, 123-131.

Cargill C, Davies P, Carmichael I, Hooke F, Moore $M$ : Treatment of sarcoptic mite infestation and mite hypersensitivity in pigs with injectable doramectin. Vet. Rec. 1996, 138, 468-471.

Cargill CF, Dobson KJ: Field and experimental studies of sarcoptic mange in pigs in south Australia. Proc. Annu. Conf. Austr. Vet. Assoc. 1977, 54, 129-131.

Cargill CF, Dobson KJ: Experimental Sarcoptes scabiei infestation in pigs: (1) Pathogenesis. Vet. Rec. 1979a, 104, 11-14.

Cargill CF, Dobson KJ: Experimental Sarcoptis scabiei infestation in pigs: (2) Effects on production. Vet. Rec. 1979b, 104, 33-36.

Courtney $\mathrm{CH}$, Ingalls WL, Stitzlein SL: Ivermectin for the control of swine scabies: Relative values of prefarrowing treatment of sows and weaning treatment of pigs. Am. J. Vet. Res. 1983, 40, 1220-1223.

Davies $P R$ : Sarcoptic mange and production performance of swine: a review of the literature and studies of associations between mite infestation, growth rate and measures of mange severity in growing pigs. Vet. Par.1995, 60, 249-264.

Henriksen SA, Ebbesen TJ: Eradication of mange mite in two sow herds (summary in English). Dansk Vet. Tidskr. 1987, 70, 530-533.

$\operatorname{Hogg} A$ : Eradication of sarcoptic mange in swine with ivermectin. Proc. Int. Pig Vet. Soc. Congr. Ghent, Belgium. 1984, 8, 206.

Hogg A: The Control and Eradication of Sarcoptic Mange in Swine Herds. Agri-Practice. 1989, 10, 6, 8-10.

Hollanders W, Harbers HM, Huige JCM, Monster P, Rambags PGM, Hendrikx WML: Control of Sarcoptes scabiei var. suis with ivermectin: influence on scratching behaviour of fattening pigs and occurence of dermatitis at slaughter. Vet. Par. 1995, $58,117-127$.

Hollanders W, Vercruysse J: Sarcoptic mite hypersensitivity: A cause of dermatitis in fattening pigs at slaughter. Vet. Rec. 1990, 126, 308-310.

Jacobson $M$, Bornstein $S$, Wallgren P: The efficacy of simplified eradication strategies against sarcoptic mange mite infections in swine herds monitored by an ELISA. Vet. Par. 1999, 81, 249-258.

Kambarage DM: Diagnosis of sarcoptic mange in pigs: Clinical examination and mite recovery as diagnostic methods in the determination of disease status. Zimbabwe Vet. J. 1993, 24, 1, 31-36.

Lambers $J H$ : Elimination of Sarcoptes scabiei in a Dutch pig breeding herd. Proc. Int .Pig Vet. Soc. Congr. Bangkok, Thailand, 1994, 13, 252.

Madsen SA: Eradication of mange in pigs with Sebacil pour-on in combination with Ivomec and Sebacil liniment 50\%. Proc. Int. Pig Vet. Soc. Congr. Lausanne, Switzerland. 1990, 11, 321.

Mikhalochkina E I: Resistance of Sarcoptes suis to environmental factors (abstract in English). Uch. Zap. Vitebsk Vet. Inst. 1975, 28, 79-80.

Nöckler K, Matthes HF, Hiepe TH, Ziegler H: Demonstration of anti-Sarcoptes suis Ig G by an indirect ELISA in neonatal blood sera from piglets infected with sarcoptic mange. Monatshefte für Veterinär-Medizin. 1992, 47, 415-421.

Pointon AM, Farrel M, Cargill CF; Heap P: A pilot pig health scheme for Australian conditions. Univ. Sydney Post.-Grad. Commun. Vet. Sci. Proc. 1987, 95, 743-777.

Schultz K, Bäckström L, Schultz R: Antibody response to antigens administered intramuscularly or in the subcutaneous fat. Proc. Int. Pig Vet. Soc. Congr. Rio de Janeiro, Brazil, 1988, 10, 27.

Sheahan BJ: Experimental Sarcoptes scabiei infection in pigs: Clinical signs and significance of infection. Vet. Rec. 1974, 94, 202-209.

Soulsby EJL: Helminths, arthropods and protozoa of domesticated animals. 7 th ed. Ballie're \& Tindall, London, 1982, 482-486.

Yeoman $G H$ : Pig mange 1: A management problem of modern systems. Livestock International. 1983, Oct/Nov. 11, 116-118.

\section{Sammanfattning}

Eliminering av Sarcoptes scabiei från svinbesättningar via enstaka eller upprepad injektion med avermectin.

Sanering mot svinskabb (S. scabiei var. suis) genomfördes i två smågrisproducerande besättningar. I besättning A behandlades samtliga individer med doramectin, två gånger med 14 dagars mellanrum. I besättning $\mathrm{B}$ behandlades samtliga individer med en enda injektion av doramectin. Ingen rengöring eller desinfektion av byggnaderna utfördes. Resultaten kontrollerades via skrapprov, klådindex och serologi avseende $S$. scabiei. Provtagning gjordes av samtliga vuxna djur och 15 smågrisar per 
besättning, var fjärde månad i totalt 20 månader. Resultaten indikerar, att saneringarna lyckats $i$ båda besättningarna och att det är möjligt att genomföra en skabbsanering med en enda avermektin-injektion till samtliga djur vid ett och samma tillfälle, utan att vidta några hygieniska åtgärder i omgivningen. Det är dock viktigt, att en korrekt dosering och en korrekt injektionsteknik används. Likaså bör nyinköpta djur placeras i karantän i minst tre veckor och där behandlas två gånger, för att undvika att smitta reintroduceras i besättningen.

(Received December 2, 1999; accepted March 5, 2000).

Reprints may be obtained from: M. Jacobsen, Department of Large Animal Clinical Sciences, Faculty of Veterinary Medicine, Swedish University of Agricultural Sciences, P.O. Box 7018, 75007 Uppsala, Sweden. E-mail: Magdalena.Jacobson@kirmed.slu.se, tel: +46-018-671475, fax: +46-018-672919 